\title{
Green practices and financial performance: A global outlook
}

\author{
Ivan Miroshnychenko*, Roberto Barontini, Francesco Testa \\ Sant'Anna School of Advanced Studies, Piazza Martiri della Libertà, 33, 56127, Pisa, Italy
}

\section{A R T I C L E I N F O}

\section{Article history:}

Received 9 September 2016

Received in revised form

10 January 2017

Accepted 10 January 2017

Available online 12 January 2017

\section{Keywords:}

Pollution prevention

Green supply chain management

Green product

ISO 14001

Financial performance

\begin{abstract}
A B S T R A C T
Companies around the world adopt green practices with the aim to reduce their environmental impacts and improve their financial performance. The present study theorizes about and empirically examines the impacts of corporate green practices on financial performance. Indexes of pollution prevention, green supply management, green product development and ISO 14001 adoption are obtained for each firm in a panel of 3490 publicly-traded companies from 58 countries over 13 years. Results show that internal green practices (pollution prevention and green supply chain management) are the major environmental drivers of financial performance, while external green practices (green product development) play a secondary role in determining financial performance. The adoption of ISO 14001 appears to have a negative impact on financial performance. This study provides empirical support for policy-makers promoting environmental practices that may lead to sustainable economic growth.
\end{abstract}

() 2017 Elsevier Ltd. All rights reserved.

\section{Introduction}

In the last few decades, the majority of companies have adopted new environmental solutions driven by search for external legitimacy (Testa et al., 2015a) or to obtain competitive success with the protection of natural resources (Haden et al., 2009). The increasing awareness of citizens on environmental degradation pushed up the demand of green products from consumers (Leonidou et al., 2013). Producers can reach customers that are willing to pay the extra costs associated with production of environmentally-friendly green products (Tsai et al., 2012), while environmental practices can increase efficiency and simultaneously reduce cost (Porter and van der Linde, 1995). An increase of eco-efficiency can provide a better access to new markets, the possibility to differentiate products or to sell innovative technology (Dangelico et al., 2013).

Pollution is generally associated with the waste of resources, lost energy and raw materials not fully utilized (Porter and van der Linde, 1995). Pollution prevention and clean technology, as internal organizational practices, can help to minimize cost and to develop sustainable skills for the future, while external organizational practices (product stewardship and sustainability vision) can help to integrate stakeholder views into business operations and to formulate future business trajectories (Hart and Milstein, 2003). Taken together, these practices can drive shareholder

\footnotetext{
* Corresponding author

E-mail address: i.miroshnychenko@sssup.it (I. Miroshnychenko).
}

value, while simultaneously contributing to a more sustainable world.

Scholars and practitioners have debated on the effectiveness of environmental actions and collaborations (Dangelico and Pontrandolfo, 2015). Many studies have analyzed whether environmental practices are able to generate a win-win situation, where a reduction of the environmental footprint determines a cost reduction or an increase of performance (Jabbour et al., 2012). However, even if most of the papers empirically support this relationship for green supply management (GSCM) and green product development (GPD) practices (Golicic and Smith, 2013), the results are controversial for pollution prevention (PP) and environmental management system (EMS) standards practices (Earnhart and Lizal, 2007).

A recent meta-analytical review of 149 studies from Endrikat et al. (2014) on the association between corporate environmental performance (CEP) and corporate financial performance (CFP) reveals a positive relationship between CEP and CFP, confirming earlier research. However, they argue that accounting for both internal and external measures of CEP and market- and accountingbased measures of CFP can yield more detailed insights about the CEP-CFP nexus, due to the multidimensional nature of both constructs. The multidimensionality of CEP derives from an amplitude of practices which contribute to the overall environmental performance and embrace other actors along the supply chain and the entire life cycle of a product (Testa et al., 2016). On the other side, the multidimensionality of CFP includes a wide array of estimations 
that may capture a firm's ability to generate value in the short term and company's future growth prospects assessed by the external stakeholders (Opler and Titman, 1995).

According to the sustainable-value framework of Hart and Milstein (2003), the purpose of a firm is to create sustainable value - "shareholder wealth that simultaneously drives us toward a more sustainable world" (p. 65) - by adoption of internal (pollution prevention and clean technology) and external (product stewardship and sustainability vision) green practices. In this study, the impacts of corporate green practices on CFP are examined following the sustainable-value framework proposed by Hart and Milstein (2003). Using a panel of 3490 publicly-traded firms from 58 countries for the period 2002-2014, this study explores whether internal and external green practices are able, individually and in combination, to improve CFP at company level. Corporate green practices' effects on both market-based and accountingbased measures of CFP are examined.

The rest of the paper is organized as follows: the next section provides an overview of the main findings emerging from the literature related to the hypotheses of the study. After that, the dataset and the estimation methodology are described. Next, the results are presented and discussed. The last section discusses the main contributions to the literature and avenues for future research.

\section{The nexus between corporate green practices and financial performance: literature review and hypotheses development}

\subsection{Pollution prevention (PP) practices and financial performance}

Minimizing waste and emission reduction associated with industrialization presents an ample opportunity for companies to develop technological competencies and organizational capabilities in PP and eco-efficiency (Hart and Milstein, 2003).

The literature suggests that emission reduction can be achieved using two major approaches: control (emissions and effluents are treated and disposed using pollution prevention equipment) or prevention approach (emissions and effluents are reduced or prevented using recycling, material substitution or innovation technologies) (Hart and Ahuja, 1996). The former approach utilizes expensive pollution control equipment 'at the end of the pipe' in order to comply with existing environmental regulations, while the latter approach is focused on reducing waste and emissions from current operations resulting in reduced compliance costs, minimal future liabilities and lower costs for raw materials and waste disposal (Sarkis and Cordeiro, 2001). Significantly better manufacturing performance has been found in those plants where environmentally-oriented investments were increasingly allocated towards PP technologies (Graham and McAdam, 2016). Reducing emissions via PP appears to be more efficient rather than control 'at the end of the pipe'.

The rationale behind PP is similar to the quality management principle that preventing manufacturing waste and emissions from current operations is a better option than finding and fixing them after they occur. Efficient PP requires substantial employee commitment, along with well-developed skills and capabilities in continuous improvement and total quality management systems (Hart and Milstein, 2003). A series of studies conducted in the U.S. has found that pollution reduction is significantly correlated with CFP over the time period 1987-1996 (King and Lenox, 2001) and for the years 1991-1996 (King and Lenox, 2002). Hart and Ahuja (1996) find that efforts to prevent pollution and reduce emissions increase CFP within one or two years of initiation. Recently, Lucas and Noordewier (2016) revealed that environmental management practices, including PP actions, have a greater effect on financial performance "in relatively dirty and non-proactive industry contexts than in relatively clean and proactive contexts". This suggests that PP practices do not provide any significant financial gain in non-polluting industries or in industries with low levels of pollution. Firm operating in industry where most of the players are already environmentally-friendly cannot obtain a first-mover advantage or profitable market differentiation via implementation of green practices.

Other studies focused on specific national contexts. Nishitani et al. (2011) show that Japanese firms that reduce pollution emissions through the prevention approach achieve a competitive advantage through not only the increase in demand on their products, but also through improvement in productivity. In the context of transition economies, there is some evidence that better PP measures have not a significant impact on CFP in the Czech republic (Earnhart and Lizal, 2007). It is likely that there is a weak consumers' environmental sensitivity in transition economies and low willingness to pay extra for low-emission products, that might explain the absence of financial benefits associated with PP practices in this context.

Taking into account theoretical arguments and empirical findings, it can be stated that PP practices can increase competitive advantage by lowering costs and risks, and allowing a firm to obtain a superior CFP. The sample analyzed in the present study is in fact dominated by large companies operating in developed countries, and also by industrial firms conducting activities in relatively dirty sectors. The first hypothesis can be formulated as the following:

Hypothesis 1. Internal PP practices have a positive impact on CFP.

\subsection{Green supply chain management (GSCM) practices and financial performance}

Besides focusing on operations under the full control of an organization, PP can be achieved by influencing suppliers and stimulating them to reduce the environmental impacts of their activities. In recent years, GSCM initiatives are seen as a fundamental part of day-to-day operations (Ketikidis et al., 2013). According to Srivastava (2007), GSCM can be defined as "integrating environmental thinking into supply chain management, including product design, material sourcing and selection, manufacturing processes, delivery of the final product to the consumers as well as end-of-life management of the product after its useful life" (p. 55). GSCM has a potential to provide a firm a first-mover advantage and can help to develop a new business model and contribute positively to overall competitiveness of a firm (Sarkis, 2003). It can also lead to environmental collaborations with customers, suppliers and other stakeholders determining both environmental and financial benefits (Dangelico and Pontrandolfo, 2015). Companies have developed a broad range of GSCM activities: written policies and communication materials, questionnaires and audits, training and technical assistance, collaborative research and development, eco-design, lean operations, supplier purchasing, purchasing policies, restructuring relationship with customers and suppliers (Golicic and Smith, 2013).

Several scholars find that manufacturing firms with high levels of GSCM practice adoption exhibit above-average accountingbased and operational performance in emerging markets (Zhu and Sarkis, 2004) and in developed economies (Testa and Iraldo, 2010). There is also some evidence in the literature that service industries benefit financially from GSCM practices as well (Carmona-Moreno et al., 2004).

In regard to the market valuation of GSCM practices, Bose and Pal (2012) analyze 104 firm announcements related to GSCM using an event study and find that plans for adopting GSCM cause a 
statistically significant gain in stock prices for a firm. They show that manufacturing firms and earlier adopters of GSCM experience stronger positive impact on their stock prices than nonmanufacturing firms. This suggests that adoption of GSCM practices is indeed valued by the market.

A recent meta-analysis covering 20 years of research on the link between GSCM practices and different CFP measures concludes that the overall effect of these practices is positive (Golicic and Smith, 2013). Given these results, it can be expected that more green firms, in terms of better GSCM practices, are likely to have a higher CFP due to improved brand image and fruitful environmental collaborations with different stakeholders. This leads to the second hypothesis:

\section{Hypothesis 2. GSCM practices have a positive impact on CFP.}

\subsection{Green product development (GPD) practices and financial performance}

The amount of firms involved in GPD is growing substantially (Dangelico et al., 2013). Environmental approaches such as ecodesign, design for environment, green marketing programs and extended producer responsibility are becoming more and more popular in the corporate landscape (Pujari, 2006).

Typically a 'green product' is defined as a product developed to minimize its environmental footprint during its entire life-cycle. Production of green products involves minimized non-renewable source usage, elimination of toxic materials, and prevention of waste at the conception stage (Albino et al., 2009). A firm can achieve a substantial cost reduction as well as opportunities to increase the quality of its services and products (Kushwaha and Sharma, 2015). Integration of environmental issues into new products leads to the creation of new opportunities for firms such as opening new markets, new technologies and product arenas (Dangelico et al., 2013). Through GPD, firms can develop unique organizational environmental capabilities that help to integrate, coordinate, build and reconfigure its resources and competences for achievement of environmental goals and sustained competitive advantage (Chen, 2008).

A recent survey of 63 studies on 'pay to be green' emphasizes that GPD provides simultaneously economic, market and financial benefits for a firm (Dangelico and Pontrandolfo, 2015). Some scholars show that firms that are actively involved in the green design of the product have a superior CFP in comparison with those who produce a small number of green products or do not do it at all (Lin et al., 2013). Kushwaha and Sharma (2015) show that green initiatives, including green products, green advertisement, ecolabels, significantly shape CFP in the automobile industry. Others document a positive impact of green products and services, and recycling activities on business performance in the wine industry (Leenders and Chandra, 2013).

On the basis of the afore-mentioned empirical findings, firms with high GPD rate are likely to experience superior CFP in comparison with firms that have no or at least no significant amount of GPD practices. This argument is summarized in the third hypothesis:

Hypothesis 3. GPD practices have a positive impact on CFP.

\subsection{Environmental management system (EMS) standards and financial performance}

The importance of EMS standards for manufacturing companies is paramount because apart from reducing firm's environmental impact, it can help a firm to develop a valuable organizational capability, which is difficult to imitate by rivals (Delmas, 2001). ISO 14001 is a largely voluntary standard which is based on a nonobligatory approach to environmental regulation (Corbett and Kirsch, 2001). It defines general requirements for how an environmental management systems should be set up according to a circular decision making scheme named Deming Cycle (HerasSaizarbitoria et al., 2013). The adoption of EMS recognized by an external certification provides a clear signal to the market of a company's commitment to environmental management (Nishitani, 2009).

Some research documents that the adoption of ISO 14001 helps a company to improve its environmental performance (Potoski and Prakash, 2005), while empirical findings on the link between EMS standards' adoption and CFP are somewhat contradictory (Heras-Saizarbitoria et al., 2011). Some scholars do not find any effect of EMS implementation on firm financial and market performance (Watson et al., 2004). Link and Naveh (2006) examined whether ISO 14001 helps Israeli firms to reduce their environmental impact and, thereby, enhance their CFP. They support the former hypothesis, but not the latter. A more recent panel analysis of 195 Spanish firms by Heras-Saizarbitoria et al. (2011) did not find that ISO 14001 implementers have better CFP than non-implementers in terms of ROA (return on assets) and sales growth. In contrast with this evidence, Feng and Wang (2016) using self-reported data from Chinese manufacturer found that EMS adoption has a positive influence on financial performance and this relationship is moderated by switching cost (negatively) and competitive intensity (positively). Further empirical research showed that the adoption of ISO 14001 leads to higher CFP at the firm level (Wahba, 2008) and improves country-level economic growth (Daddi et al., 2015).

Given that a large stream of literature emphasizes the significant role of ISO standards in driving CFP (Feng and Wang, 2016), it can be argued that ISO 14001 can have a positive impact on CFP due to the fact that stakeholders' involvement in a firm's ISO 14001 can become a valuable and unique organizational capability (Delmas, 2001). The fourth hypothesis can be stated as follows:

Hypothesis 4. ISO 14001 adoption has a positive impact on CFP.

\section{Methodology}

\subsection{Data description}

The starting point of data collection is a Thomson Reuters dataset, namely the ASSET4 full universe list, provided by team of 130 analysts that systematically collects environmental, social and governance (ESG) data covering constituents of principal stock indices. ASSET4 strictly sources publicly available information, including sustainability/CSR reports, company websites, annual reports, proxy filings, as well as news of all major providers.

In contrast to the KLD database that provides ESG data only for listed US companies, ASSET4 has more representative population of publicly-traded companies worldwide, and provides more comprehensive calculation of the rating scores (Shaukat et al., 2015). Around 900 data points are used as inputs to calculate 250 key performance indicators (KPIs). These KPIs are further classified into 18 categories within four pillars: environmental, social, corporate governance and economic. The availability of disaggregated ASSET4 data allowed the authors to model individual and combined effects of heterogeneous green practices on CFP (as described further in Section 3.2) taking into account the inherent multidimensionality of CEP (Endrikat et al., 2014). 
Table 1

Sample composition.

\begin{tabular}{|c|c|c|c|c|}
\hline & \multicolumn{4}{|c|}{ Total number of firms 3490} \\
\hline & \multicolumn{2}{|l|}{ Financial data } & \multicolumn{2}{|c|}{ Environmental data } \\
\hline & $\begin{array}{l}\text { Number of } \\
\text { observations }\end{array}$ & $\begin{array}{l}\% \text { of } \\
\text { sample }\end{array}$ & $\begin{array}{l}\text { Number of } \\
\text { observations }\end{array}$ & $\begin{array}{l}\% \text { of } \\
\text { sample }\end{array}$ \\
\hline $\begin{array}{c}\text { Incumbent firms in all } \\
\text { period } 2002-2014\end{array}$ & 31,083 & 76.81 & 6331 & 24.83 \\
\hline $\begin{array}{l}\text { Firms entering in the } \\
\text { period 2002-2014 }\end{array}$ & 7485 & 18.50 & 17,266 & 67.72 \\
\hline $\begin{array}{l}\text { Firms exiting in the } \\
\text { period 2002-2014 }\end{array}$ & 1899 & 4.69 & 1899 & 7.45 \\
\hline Total & 40,467 & 100.00 & 25,496 & 100.00 \\
\hline
\end{tabular}

In order to ensure high data quality, every piece of information is subject to a multi-step verification and process control, which includes a series of data entry checks, automated quality rules and historical comparisons. Different investors representing more than 2,5 trillion in assets under management - like the prominent investment house BlackRock - build their portfolios by integrating ESG data into their traditional investment analysis (Cheng et al., 2014). A number of recent studies in both environmental management (Shaukat et al., 2015) and finance literature (Halbritter and Dorfleitner, 2015) have used ASSET4 ESG data as well.

The ASSET4 full universe list covers ESG performance of 5059 industrial, utility, transportation and financial publicly-traded corporations from America, Africa, Asia and Europe starting from the fiscal year 2002. Industries where environmental activities do not matter or matter little at most (aerospace, financial, recreation, retailers, tobacco, drugs, cosmetics and healthcare industries) have been excluded. Financial and accounting firm-level data have been collected from Thompson Reuters Datastream. In total, the final sample includes 3490 publicly-traded firms from 58 countries and 19 industrial sectors covering the period from 2002 till 2014 inclusively.

As shown in Table 1, there are three types of firms in the sample: a) firms existing in the ASSET4 full universe list for the entire period of analysis (2002-2014); b) firms entering the sample during the period of analysis (2002-2014); c) firms exiting during the period of analysis (2002-2014) if they become privately held, merged, liquidated or otherwise inactive. This allows the present study to mitigate the survivorship bias problem, because statistical inferences can be biased if a study does not include firms that did not exist till the end of the period.

The breakdown by countries shows that the largest part of the sample belongs to the US (23.64\% of the total), the world's largest economy, while other Anglo-Saxon countries (Australia, Canada and the UK), weigh in the sample around $26.16 \%$. Some $12.72 \%$ of the sample belong to the European Union (EU). Other countries show a fairly widespread distribution, with the exception of Japan that has around 4225 observations representing $9.31 \%$ of the sample. The sample comprises primarily from the manufacturing firms $(84.90 \%)$, while utilities and transportation represent only $10.63 \%$ and $4.47 \%$ of the sample. Electronics (12.58\%), oil and gas (11.24\%) are the most represented manufacturing firms in the sample.

\subsection{Variables}

Concerning dependent variable, extent research on CFP widely uses either market-based indicators that capture firm's current and future gains (Tobin's q, market capitalization, stock market performance), and/or accounting-based indicators (i.e., return on equity (ROE), ROA, return on sales (ROS)) that capture a firm's current ability to create value by using its assets (Sánchez-Ballesta and García-Meca, 2007). Tobin's q and ROE have been used to account for both market- and accounting-based measures of CFP.

Tobin's q is estimated as the ratio between (book value of total assets - book value of shareholder's equity + market value of shareholder's equity) and (book value of total assets).

$\mathrm{ROE}$ is defined as (net income - preferred dividend requirements) divided by the average of last year's and current year's common equity. To reduce the weight of extreme outliers, Tobin's q and ROE have been winsorized at the 5th and 95th percentiles.

As independent variables, four types of corporate green practices, namely PP, GSCM, GPD and ISO 14001, have been considered as determinants of CFP.

In order to capture the individual and integrated effects of green practices on CFP, internal PP Index (PPI), GSCM Index (GSCMI) and Green Product Index (GPI) have been constructed using KPIs from emission reduction, resource reduction and product innovation categories of the environmental pillar of ASSET4. The resource reduction category measures a company's management commitment and effectiveness towards achieving an efficient use of natural resources in the production process. The emission reduction category measures a company's management commitment and effectiveness towards reducing environmental emission in the production and operational processes. The product innovation category measures a company's management commitment and effectiveness towards supporting the R\&D of eco-efficient products or services. All three afore-mentioned categories form an environmental pillar of ASSET4 that assesses an overall company's impact on living and non-living natural systems (ASSET4 documents).

To measure internal $P P$ actions the authors referred to initiatives carried out by organizations to reduce or improve specific environmental performance and that are mentioned in previous research on PP practices, that is: air emission (Hart and Ahuja, 1996); nitrogen and sulfur oxides emission (Hoque and Clarke, 2013); waste and e-waste reduction (Franchetti, 2011); particular matter and volatile organic compounds emission (Newbold, 2006); emission from transport (Comoglio and Botta, 2012); water and energy efficiency (Gusmerotti et al., 2012); toxic chemicals reduction (Nishitani et al., 2011).

The following practices of GSCM have been included to develop the construct GSCM Index: implementation of processes to include supply chain in the company's efforts to lessen its overall environmental impact (Srivastava, 2007); use of environmental criteria to source or eliminate materials (Sarkis, 2003); use of environmental criteria in the selection process of suppliers (Testa and Iraldo, 2010); phasing out selection procedures (Handfield et al., 2005).

To measure Green Product Index (GPI) the authors selected practices aiming to reduce the environmental impact of a product such as complying with an environmental performance product standard (Testa et al., 2015b), producing a product which promotes a cost-effective and environmentally preferable use (Nissinen et al., 2007), and eco-design practices (Zhu et al., 2005).

The dummy variable ISO was constructed to measure the adoption of environmental management standards (equals one if the company has either ISO 14001 certification, or both ISO 14001 and EMS certifications, and zero otherwise) following Testa et al. (2014). Table 2 provides a detailed description of all the green practices' proxies. 
Table 2

Definition of green practices.

\begin{tabular}{|c|c|}
\hline Variable & Description \\
\hline $\begin{array}{l}\text { Internal Pollution Prevention Index } \\
\text { (PPI) }\end{array}$ & $\begin{array}{l}\text { Sum of the } 10 \text { emission and resource reduction KPIs: } \\
\text { 1. Emissions (Does the company describe, claim to have or mention processes in place to improve emission reduction?-Yes }=1 / \\
\text { No }=0 \text { ); } \\
\text { 2. Nitrogen oxides (NOx) and Sulfur Oxides (SOx) Emissions Reduction (Does the company report on initiatives to reduce, reuse, } \\
\text { recycle, substitute, or phase out SOx or NOx emissions?-Yes }=1 / \mathrm{No}=0 \text { ); } \\
\text { 3. Volatile Organic Compounds }(\mathrm{VOC} \text { ) Emissions Reductions (Does the company report on initiatives to reduce, substitute, or phase } \\
\text { out VOC?-Yes }=1 / \mathrm{No}=0 \text { ); } \\
\text { 4. Particular Matter Emissions Reductions (Does the company report on initiatives to reduce, substitute, or phase out particulate } \\
\text { matter less than ten microns in diameter (PM10)?- Yes }=1 / \text { No }=0 \text { ); } \\
\text { 5. Waste Reduction Total (Does the company report on initiatives to recycle, reduce, reuse, substitute, treat or phase out total } \\
\text { waste?-Yes }=1 / \text { No }=0 \text { ); } \\
\text { 6. e-Waste Reduction (Does the company report on initiatives to recycle, reduce, reuse, substitute, treat or phase out e-waste?- } \\
\text { Yes }=1 / \text { No }=0 \text { ); } \\
\text { 7. Staff Transportation Impact Reduction (Does the company report on initiatives to reduce the environmental impact of } \\
\text { transportation used for its staff?-Yes }=1 / \text { No }=0 \text { ); } \\
\text { 8. Water Efficiency (Does the company describe, claim to have or mention processes in place to improve its water efficiency?- } \\
\text { Yes }=1 / \text { No }=0 \text { ); } \\
\text { 9. Energy Efficiency (Does the company describe, claim to have or mention processes in place to improve its energy efficiency?- } \\
\text { Yes }=1 / \text { No }=0 \text { ); } \\
\text { 10. Toxic Chemicals or Substances Reduction (Does the company report on initiatives to reduce, reuse, substitute or phase out toxic } \\
\text { chemicals or substances?-Yes }=1 / \text { No }=0 \text { ); } \\
\text { The PPI ranges from } 0 \text { (highest polluters) to } 10 \text { (lowest polluters). }\end{array}$ \\
\hline $\begin{array}{l}\text { Green Supply Chain Management } \\
\text { Index (GSCMI) }\end{array}$ & $\begin{array}{l}\text { Sum of the } 4 \text { resource reduction KPIs: } \\
\text { 1. Environmental Supply Chain (Does the company describe, claim to have or mention processes in place to include its supply chain } \\
\text { in the company's efforts to lessen its overall environmental impact?-Yes }=1 / \mathrm{No}=0 \text { ); } \\
\text { 2. Materials Sourcing Environmental Criteria (Does the company claim to use environmental criteria (e.g., life cycle assessment) to } \\
\text { source or eliminate materials?-Yes }=1 / \mathrm{No}=0 \text { ); } \\
\text { 3. Environmental Supply Chain Management (Does the company use environmental criteria (ISO } 14001 \text {, energy consumption, etc.) } \\
\text { in the selection process of its suppliers or sourcing partners?-Yes }=1 / \text { No }=0 \text { ); } \\
\text { 4. Environment Supply Chain Partnership Termination (Does the company report or show to be ready to end a partnership with a } \\
\text { sourcing partner, if environmental criteria are not met?-Yes }=1 / \text { No }=0 \text { ); } \\
\text { The GSCMI ranges from } 0 \text { (weak GSCM practices) to } 4 \text { (strong GSCM practices). }\end{array}$ \\
\hline Green Product Index (GPI) & $\begin{array}{l}\text { Sum of the } 3 \text { product innovation KPIs: } \\
\text { 1. Environmental Products (Does the company report on at least one product line or service that is designed to have positive effects } \\
\text { on the environment or which is environmentally labeled and marketed?-Yes }=1 / \text { No }=0 \text { ); } \\
\text { 2. Product Environmental Responsible Use (Does the company report about product features and applications or services that will } \\
\text { promote responsible, efficient, cost-effective and environmentally preferable use?-Yes }=1 / \text { No }=0 \text { ); } \\
\text { 3. Eco-design Products (Does the company report on specific products which are designed for reuse, recycling or the reduction of } \\
\text { environmental impacts?-Yes }=1 / \text { No }=0 \text { ); } \\
\text { The GPI ranges from } 0 \text { (weak GPD practices) to } 3 \text { (strong GPD practices). }\end{array}$ \\
\hline ISO 14001 (ISO) & ISO 14001 (Does the company claim to have an ISO 14001 certification?-ISO or both ISO and EMS $=1$, and otherwise $=0$ ) \\
\hline
\end{tabular}

As control variables, in all the models financial leverage, sales growth, firm size, country, industry and year dummies have been included.

Given that firms with high indebtedness experience significant financial constraints and, ultimately, deliver inferior CFP (Gleason et al., 2000), the leverage ratio is included in the present study as a proxy of financial distress (estimated as the ratio of total debt to total assets). There is also a vast amount of research that suggests that sales growth has a positive influence on firm profitability (Delmar et al., 2013). The log-difference of net sales for firm $i$ between time $t$ and $t-1$ is adopted as a proxy of the sales growth (García-Manjón and Romero-Merino, 2012). The natural logarithm of total assets has been included in all the regressions to control for the effect of firm size (Becker-Blease et al., 2010). Country, industry and year dummies have been included in order to capture the heterogeneity across different countries, industrial sectors and time periods.

\subsection{Econometric model}

Equation (1) has been used as the main explanatory model to test both the individual and combined effects of corporate green practices (PPI, GSCMI, GPI and ISO 14001) on CFP, which is a leadlag approach after controlling for country-, industry- and yearfixed effects. Since the causality link between corporate green practices and CFP can run in both directions (Endrikat et al., 2014), potentially endogenous corporate green practices' measures and control variables have been lagged to minimize the simultaneity issues ( $\mathrm{Ng}$ and Rezaee, 2015). Independent variables at time $t-1$ have been used instead of any other further lags due to missing values, mainly in green practices' variables. Taking other lags will result in losing a substantial number of observations leading to a significant reduction in sample size.

$$
\begin{aligned}
\operatorname{Per}_{i t}= & \beta_{0}+\beta_{1}\left(\text { PPI }_{i t-1}\right)+\beta_{2}\left(\text { GSCMI }_{i t-1}\right)+\beta_{3}\left(\text { GPI }_{i t-1}\right) \\
& +\beta_{4}\left(\text { ISO }_{i t-1}\right)+\beta_{5}\left(\text { Controls }_{i t-1}\right)+d_{t}+c_{i}+i_{i}+\varepsilon_{i t}
\end{aligned}
$$

where $P e r_{i t}$ is a proxy of CFP (measured as Tobin's q or ROE), $P P I_{i t-1}$ is a proxy for a firm's pollution prevention, $G_{S C M I}$ it-1 is a proxy for a firm's green supply chain management, SPI $_{i t-1}$ is a proxy for a firm's green product development, $I S O_{i t-1}$ is a proxy for a firm's environmental management standards, Controls $s_{i-1}$ is a vector of control variables that include financial leverage (total debt-to-total assets ratio), sales growth (difference of logs of net sales) and firm size (the natural logarithm of total assets). $d_{t}, c_{i}$ and $i_{i}$ represent time, country and industry dummies. $\varepsilon_{i t}$ is an error term.

The ordinary least squares (OLS) estimator has been adopted to estimate the main explanatory model. While the autocorrelation problem is of serious concern in macro panels consisting of long time series over 20-30 years (Baltagi, 2008), the authors estimate 
the OLS regressions in micro panel using the Huber-White sandwich estimator, to account for the heteroscedasticity problem (Long and Ervin, 2000). A series of univariate tests have been performed as well to compare whether the mean differences and median differences in green practices and in financial performance across European countries and the rest of the world are statistically significant (Table 3). The results indicate that European countries have higher PPI and GSCMI in comparison with the rest of the world. European countries are the second strongest cluster in GPI and ISO after Japan. The authors also find statistically significant differences in terms of both Tobin's q and ROE between European states and other countries.

Correlations for the key variables used in the paper are presented in Table 4 . The authors observe statistically significant correlations between green practices' measures suggesting that multicollinearity might be a problem. The variance inflation factors (VIF) of all the independent and control variables were calculated to test the effects of multicollinearity in the regression analysis. The mean VIF values in all the models (with a minimum of 2.76 and maximum of 2.82) indicate the absence of the multicollinearity (O’Brien, 2007).

\section{Results \& discussion}

\subsection{The impacts of green practices on CFP}

Table 5 reports the main findings using both Tobin's q and ROE as CFP proxies. In order to examine both the individual and combined effects of green practices on CFP, green practices' variables have been included in the model as follows: with models (1) and (2) including only PPI and control variables, models (3) and (4) GSCMI, models (5) and (6) GPI, models (7) and (8) ISO, models (9) and (10) taking acount of the all green practices simultaneously.

As shown in models (1) and (2), the regression coefficients suggest that reduced pollution is correlated with CFP not only in the
U.S. (King and Lenox, 2001), but also across the rest of the world. According to Hart and Ahuja (1996) the results confirm that reduction of pollutant emissions increase internal efficiency and consequently company's profitability. Differently from them, it clarifies that the return of green investment is even shorter than 3 years. Additionally, the results confirm what Ambec and Lanoie (2008) hypothesized that external investors, as highlighted by the positive and significant relation between PPI and Tobin's q, reward the reduction of environmental risks in capital markets.

In models (3) and (4) a positive and highly statistically significant effect of GSCMI on CFP is documented, confirming the positive relationship between operating performance of a firm and GSCMI as highlighted in previous research focused on specific sectors (Testa and Iraldo, 2010) or geographical contexts (Zhu and Sarkis, 2004). The empirical findings of this study integrate the main conclusion reached by the event analysis carried out by Bose and Pal (2012). Not only GSCM announcements have immediate positive effects on stock prices of a company on the day of announcement, but GSCM practices increase a future company's valuation as well.

As regards GPI, the empirical model reveals a positive and highly significant impact on both Tobin's q and ROE (models 5 and 6). This result sheds a definitive light on the positive effect of green product initiatives on company's profitability and value of a firm by confirming findings from previous research that included these practices in larger dimension of green initiatives (Lin et al., 2013) or results of prior research focused on specific industry context (see Kushwaha and Sharma, 2015). Operators of capital markets and final consumers are by the time mature on environmental issues related to products. The former recognizes the ability of eco-design and environmental product initiatives to satisfy the ever-increasing market segments and generate long-lasting revenues (Ambec and Lanoie, 2008). The latter shows their will to valorize the green attributes of a product among the selection criteria used in their purchasing decisions (Darnall et al., 2016).

Table 3

Descriptive data of the sample.

\begin{tabular}{|c|c|c|c|c|c|c|c|c|c|c|c|}
\hline Country & & & $\mathrm{Q}$ & ROE & Leverage & Growth & Size & PPI & GSCMI & GPI & ISO \\
\hline \multirow[t]{3}{*}{ All countries } & $100.00 \%$ & Mean & 1.705 & 0.120 & 0.246 & 0.121 & 16.033 & 2.598 & 1.016 & 0.792 & 0.489 \\
\hline & & Median & 1.401 & 0.118 & 0.235 & 0.081 & 15.694 & 2.000 & 0.000 & 0.000 & 0.000 \\
\hline & & Std. Dev. & 0.871 & 0.159 & 0.180 & 0.299 & 2.931 & 2.449 & 1.347 & 1.090 & 0.500 \\
\hline \multirow[t]{3}{*}{ EU } & $12.72 \%$ & Mean & 1.525 & 0.129 & 0.272 & 0.061 & 15.681 & 3.314 & 1.541 & 1.016 & 0.692 \\
\hline & & Median & 1.312 & 0.130 & 0.261 & 0.050 & 15.602 & 3.000 & 1.000 & 1.000 & 1.000 \\
\hline & & Std. Dev. & 0.700 & 0.151 & 0.164 & 0.217 & 1.673 & 2.486 & 1.501 & 1.152 & 0.462 \\
\hline \multirow[t]{3}{*}{ Australia } & $9.80 \%$ & Mean & $1.895^{* * *}$ & $0.054^{* * *}$ & $0.176^{* * *}$ & $0.232^{* * *}$ & $12.466^{* * *}$ & $1.606^{* * *}$ & $0.535^{* * *}$ & $0.429^{* * *}$ & $0.257^{* * *}$ \\
\hline & & Median & $1.509^{* * *}$ & $0.071^{* * *}$ & $0.138^{* * *}$ & $0.117^{* * *}$ & $12.516^{* * *}$ & $0.000^{* * *}$ & $0.000^{* * *}$ & $0.000^{* * * *}$ & $0.000^{* * *}$ \\
\hline & & Std. Dev. & 1.055 & 0.201 & 0.183 & 0.557 & 2.229 & 2.038 & 1.043 & 0.823 & 0.437 \\
\hline \multirow[t]{3}{*}{ Canada } & $8.54 \%$ & Mean & $1.766^{* * *}$ & $0.056^{* * *}$ & $0.207^{* * *}$ & $0.187^{* * *}$ & $13.755^{* * *}$ & $1.902^{* * *}$ & $0.415^{* * *}$ & $0.350^{* * *}$ & $0.221^{* * *}$ \\
\hline & & Median & $1.468^{* * *}$ & $0.066^{* * *}$ & $0.194^{* * *}$ & $0.118^{* * *}$ & $13.900^{* * *}$ & $1.000^{* * *}$ & $0.000^{* * *}$ & $0.000^{* * *}$ & $0.000^{* * *}$ \\
\hline & & Std. Dev. & 0.920 & 0.167 & 0.175 & 0.401 & 2.021 & 2.302 & 0.915 & 0.722 & 0.415 \\
\hline \multirow[t]{3}{*}{ Japan } & $9.31 \%$ & Mean & $1.303^{* * *}$ & $0.067^{* * *}$ & $0.260^{* * *}$ & $0.048^{* * *}$ & $20.302^{* * *}$ & $3.143^{* * *}$ & $1.348^{* * *}$ & $1.252^{* * *}$ & $0.754^{* * *}$ \\
\hline & & Median & $1.118^{* * *}$ & $0.066^{* * *}$ & $0.244^{* * *}$ & $0.041^{* * *}$ & $20.197^{* * *}$ & $3.000^{* *}$ & $1.000^{* * *}$ & $1.000^{* * *}$ & $1.000^{* * *}$ \\
\hline & & Std. Dev. & 0.597 & 0.100 & 0.191 & 0.175 & 1.275 & 2.430 & 1.363 & 1.254 & 0.431 \\
\hline \multirow[t]{3}{*}{ USA } & $23.64 \%$ & Mean & $1.921^{* * *}$ & 0.130 & $0.260^{* * *}$ & $0.098^{* * *}$ & $15.323^{* * *}$ & $2.158^{* * *}$ & $0.796^{* * *}$ & $0.737^{* * *}$ & $0.286^{* * *}$ \\
\hline & & Median & $1.615^{* * *}$ & 0.131 & $0.248^{* * *}$ & $0.079^{* * *}$ & $15.257^{* * *}$ & $1.000^{* * *}$ & $0.000^{* * *}$ & $0.000^{* * *}$ & $0.000^{* * *}$ \\
\hline & & Std. Dev. & 0.907 & 0.157 & 0.183 & 0.230 & 1.380 & 2.493 & 1.264 & 1.070 & 0.452 \\
\hline \multirow[t]{3}{*}{ UK } & $7.82 \%$ & Mean & $1.783^{* * *}$ & $0.160^{* * *}$ & $0.223^{* * *}$ & $0.094^{* * *}$ & $13.857^{* * *}$ & $2.757^{* * *}$ & $1.243^{* * *}$ & $0.627^{* * *}$ & $0.600^{* * *}$ \\
\hline & & Median & $1.522^{* * *}$ & $0.155^{* * *}$ & $0.204^{* * *}$ & $0.066^{* * *}$ & $13.766^{* * *}$ & $3.000^{* * *}$ & $1.000^{* * *}$ & $0.000^{* * *}$ & $1.000^{* * *}$ \\
\hline & & Std. Dev. & 0.840 & 0.165 & 0.18 & 0.238 & 1.628 & 2.050 & 1.354 & 0.970 & 0.490 \\
\hline \multirow[t]{3}{*}{ Others } & $28.17 \%$ & Mean & $1.654^{* * *}$ & $0.156^{* * *}$ & $0.258^{* * *}$ & $0.149^{* * *}$ & $17.605^{* * *}$ & $2.760^{* * *}$ & $0.954^{* * *}$ & $0.750^{* * * *}$ & $0.551^{* * *}$ \\
\hline & & Median & $1.362^{* * *}$ & $0.145^{* * *}$ & $0.251^{* * *}$ & $0.119^{* * *}$ & $17.272^{* * *}$ & $3.000^{* * *}$ & $0.000^{* * *}$ & $0.000^{* * *}$ & $1.000^{* * *}$ \\
\hline & & Std. Dev. & 0.849 & 0.144 & 0.173 & 0.272 & 2.668 & 2.425 & 1.313 & 1.056 & 0.500 \\
\hline
\end{tabular}

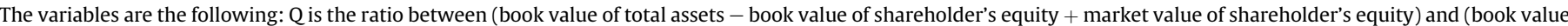

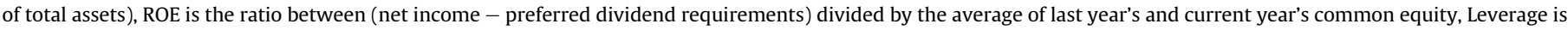

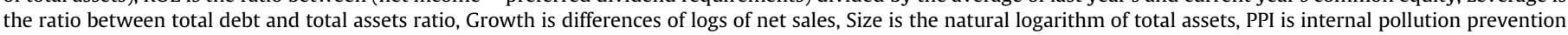

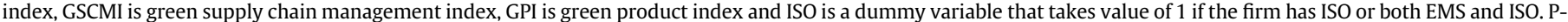

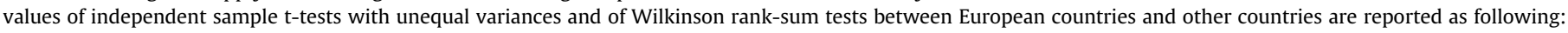
$\dagger \mathrm{p}<, 10 ;{ }^{*} \mathrm{p}<, 05 ;{ }^{* *} \mathrm{p}<, 01 ;{ }^{* * *} \mathrm{p}<, 001$. 
Table 4

Correlation coefficient matrix.

\begin{tabular}{|c|c|c|c|c|c|c|c|c|c|}
\hline Variable & 1 & 2 & 3 & 4 & 5 & 6 & 7 & 8 & 9 \\
\hline $1 \mathrm{Q}$ & 1.00 & & & & & & & & \\
\hline $2 \mathrm{ROE}$ & $0.46^{* * * *}$ & 1.00 & & & & & & & \\
\hline 3 Leverage & $-0.27^{* * *}$ & $-0.10^{* * *}$ & 1.00 & & & & & & \\
\hline 4 Growth & $0.18^{* * *}$ & $0.17^{* * *}$ & $-0.05^{* * *}$ & 1.00 & & & & & \\
\hline 5 Size & $-0.29^{* * *}$ & $-0.06^{* * *}$ & $0.19^{* * *}$ & $-0.06^{* * *}$ & 1.00 & & & & \\
\hline 6 PPI & $-0.15^{* * *}$ & $-0.02^{*}$ & $0.08^{* * *}$ & $-0.13^{* * *}$ & $0.33^{* * *}$ & 1.00 & & & \\
\hline 7 GSCMI & $-0.11^{* * *}$ & -0.01 & $0.04^{* * *}$ & $-0.12^{* * *}$ & $0.23^{* * *}$ & $0.64^{* * *}$ & 1.00 & & \\
\hline 8 GPI & $-0.13^{* * *}$ & $-0.05^{* * *}$ & $0.02^{* * *}$ & $-0.13^{* * *}$ & $0.25^{* * *}$ & $0.54^{* * *}$ & $0.54^{* * *}$ & 1.00 & \\
\hline 9 ISO & $-0.18^{* * *}$ & $-0.02^{* * *}$ & $0.04^{* * *}$ & $-0.11^{* * *}$ & $0.31^{* * *}$ & $0.48^{* * *}$ & $0.43^{* * *}$ & $0.38^{* * *}$ & 1.00 \\
\hline
\end{tabular}

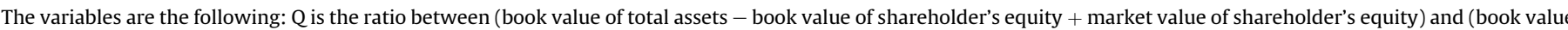

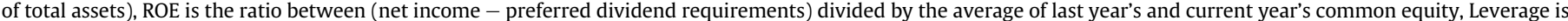

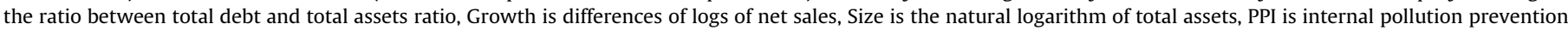

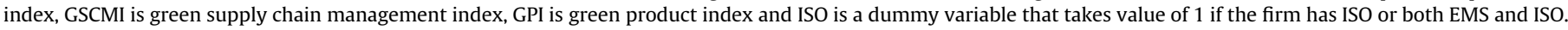
$\dagger \mathrm{p}<, 10 ;{ }^{*} \mathrm{p}<, 05 ;{ }^{* *} \mathrm{p}<, 01 ;{ }^{* * *} \mathrm{p}<, 001$.

Table 5

The impacts of green practices on CFP.

\begin{tabular}{|c|c|c|c|c|c|c|c|c|c|c|}
\hline \multirow{2}{*}{$\begin{array}{l}\text { Dependent } \\
\text { variable }\end{array}$} & \multirow{2}{*}{$\frac{\mathrm{Q}}{\text { Model (1) }}$} & \multirow{2}{*}{$\frac{\text { ROE }}{\text { Model (2) }}$} & \multirow{2}{*}{$\frac{Q}{\text { Model (3) }}$} & \multirow{2}{*}{$\frac{\text { ROE }}{\text { Model (4) }}$} & \multirow{2}{*}{$\frac{\mathrm{Q}}{\text { Model (5) }}$} & \multirow{2}{*}{$\frac{\text { ROE }}{\text { Model (6) }}$} & \multirow{2}{*}{$\frac{\mathrm{Q}}{\operatorname{Model}(7)}$} & \multirow{2}{*}{$\frac{\text { ROE }}{\text { Model (8) }}$} & \multirow{2}{*}{$\frac{\mathrm{Q}}{\text { Model (9) }}$} & \multirow{2}{*}{$\frac{\text { ROE }}{\text { Model (10) }}$} \\
\hline & & & & & & & & & & \\
\hline \multirow{2}{*}{ Constant } & $4.631^{* * *}$ & $0.158^{* * *}$ & $4.507^{* * *}$ & $0.138^{* * *}$ & $4.409^{* * *}$ & $0.129^{* * *}$ & $4.186^{* * * *}$ & $0.116^{* * *}$ & $4.629^{* * *}$ & $0.162^{* * * *}$ \\
\hline & $(46.31)$ & $(8.70)$ & $(46.01)$ & $(7.82)$ & $(45.18)$ & (7.33) & $(43.20)$ & $(6.64)$ & $(46.57)$ & $(8.83)$ \\
\hline \multirow[t]{2}{*}{ Leverage } & $-0.578^{* * *}$ & $-0.046^{* * *}$ & $-0.583^{* * *}$ & $-0.047^{* * *}$ & $-0.591^{* * *}$ & $-0.048^{* * *}$ & $-0.605^{* * *}$ & $-0.049^{* * *}$ & $-0.570^{* * *}$ & $-0.045^{* * *}$ \\
\hline & $(-16.22)$ & $(-5.97)$ & $(-16.32)$ & $(-6.07)$ & $(-16.54)$ & $(-6.20)$ & $(-16.92)$ & $(-6.37)$ & $(-16.03)$ & $(-5.83)$ \\
\hline \multirow[t]{2}{*}{ Growth } & $0.331^{* * *}$ & $0.064^{* * *}$ & $0.322^{* * *}$ & $0.063^{* * *}$ & $0.320^{* * *}$ & $0.062^{* * *}$ & $0.308^{* * *}$ & $0.062^{* * *}$ & $0.325^{* * *}$ & $0.064^{* * *}$ \\
\hline & (13.81) & $(11.72)$ & $(13.44)$ & $(11.50)$ & (13.35) & (11.48) & (12.81) & (11.36) & (13.61) & $(11.71)$ \\
\hline \multirow[t]{2}{*}{ Size } & $-0.193^{* * *}$ & $-0.003^{* *}$ & $-0.185^{* * *}$ & $-0.002 \dagger$ & $-0.175^{* * *}$ & -0.001 & $-0.160^{* * *}$ & 0.000 & $-0.194^{* * *}$ & $-0.003^{* * *}$ \\
\hline & $(-37.72)$ & $(-3.09)$ & $(-37.39)$ & $(-1.77)$ & $(-36.33)$ & $(-0.76)$ & $(-33.59)$ & $(0.17)$ & $(-37.69)$ & $(-3.34)$ \\
\hline \multirow[t]{2}{*}{ PPI } & $0.032^{* * *}$ & $0.004^{* * *}$ & & & & & & & $0.027^{* * *}$ & $0.003^{* * *}$ \\
\hline & $(13.46)$ & $(8.18)$ & & & & & & & (9.19) & $(5.37)$ \\
\hline \multirow{2}{*}{ GSCMI } & & & $0.054^{* * *}$ & $0.006^{* * * *}$ & & & & & $0.038^{* * *}$ & $0.003^{* *}$ \\
\hline & & & $(12.51)$ & $(6.68)$ & & & & & $(7.71)$ & $(2.87)$ \\
\hline \multirow[t]{2}{*}{ GPI } & & & & & $0.046^{* * *}$ & $0.006^{* * *}$ & & & $0.021^{* * * *}$ & $0.003^{*}$ \\
\hline & & & & & $(8.58)$ & $(5.34)$ & & & $(3.56)$ & $(2.04)$ \\
\hline \multirow[t]{2}{*}{ ISO } & & & & & & & $-0.050^{* * *}$ & 0.003 & $-0.125^{* * *}$ & $-0.005 \dagger$ \\
\hline & & & & & & & $(-4.40)$ & (1.46) & $(-10.23)$ & $(-1.95)$ \\
\hline \multirow[t]{2}{*}{$\mathrm{Z}_{1}$} & 0.000 & 0.000 & 0.000 & 0.000 & 0.000 & 0.000 & 0.000 & 0.000 & 0.000 & 0.000 \\
\hline & $(88)$ & $(88)$ & $(88)$ & $(88)$ & $(88)$ & $(88)$ & $(88)$ & $(88)$ & (91) & $(91)$ \\
\hline $\mathrm{Z}_{2}(10)$ & 0.000 & 0.000 & 0.000 & 0.000 & 0.000 & 0.000 & 0.000 & 0.000 & 0.000 & 0.000 \\
\hline$Z_{3}(55)$ & 0.000 & 0.000 & 0.000 & 0.000 & 0.000 & 0.000 & 0.000 & 0.000 & 0.000 & 0.000 \\
\hline$Z_{4}(19)$ & 0.000 & 0.000 & 0.000 & 0.000 & 0.000 & 0.000 & 0.000 & 0.000 & 0.000 & 0.000 \\
\hline $\mathrm{N}$ & 21,471 & 21,055 & 21,471 & 21,055 & 21,466 & 21,050 & 21,472 & 21,056 & 21,465 & 21,049 \\
\hline Adj. $R^{2}$ & 0.278 & 0.134 & 0.277 & 0.133 & 0.274 & 0.133 & 0.273 & 0.132 & 0.283 & 0.135 \\
\hline
\end{tabular}

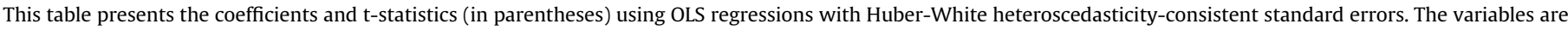

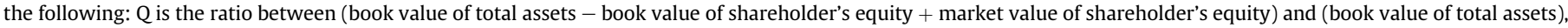

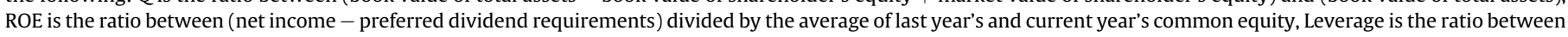

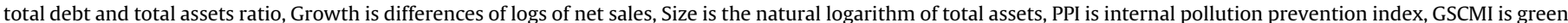

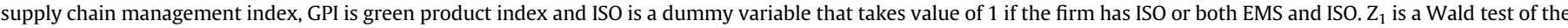

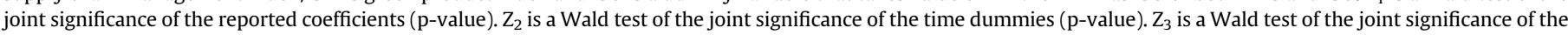
country dummies (p-value). $\mathrm{Z}_{4}$ is a Wald test of the joint significance of the industry dummies ( $\mathrm{p}$-value). $\dagger \mathrm{p}<, 10 ;{ }^{*} \mathrm{p}<, 05 ;{ }^{* *} \mathrm{p}<, 01 ;{ }^{* * *} \mathrm{p}<, 001$.

In model (7), it emerges that the adoption of a certified EMS has a slight negative and statistically significant impact on CFP, measured as Tobin's q. This result suggests that investors tend to perceive the adoption of EMS standard as an unreliable initiative to reduce environmental risks and improve environmental performance. Even if this result can be considered unexpected, it confirms the risk of credibility loss that these kind of standards have to face in the upcoming years. As emphasized by an emerging piece of EMS literature, the vagueness of the standard's requirements (HerasSaizarbitoria and Boiral, 2013) as well as the lack of professionality in the external auditors (Heras-Saizarbitoria et al., 2013) allow the adopters to have a wide margine of manouvre in EMS implementation (Boiral, 2007) and can produce a new form of symbolic greenwashing (Testa et al., 2015b). These considerations all explain the fact that the coefficient of ISO in model (8) is not statistically significant, which means that the relation between
EMS standards and business performance remains unclear. This represents a further evidence of what Iraldo et al. (2009) found in their empirical model: the link between EMS adoption and business performance depends on how an organization integrates the standard requirements in its strategy and operations.

The above mentioned conclusions are confirmed also in the comprehensive models (models 9 and 10), where PPI, GSCMI and GPI have positive and highly statistically significant effects on CFP.

Concerning the control variables, as expected, sales growth is strongly and positively related to CFP in all the models (Delmar et al., 2013). The authors also observe that the leverage ratio influences negatively CFP as postulated by prior research (Gleason et al., 2000). Firm size is negatively associated with CFP (BeckerBlease et al., 2010) and this effect is more pronounced for Tobin's q. The Wald tests of the joint significance of the country, industry and time dummies justify inclusion of country-, industry- and year- 
fixed effects.

To further capture the percentage reaction in CFP to percentage change in green practices, the elasticities of all green practices have been estimated at sample means. Table 6 shows elasticities of the green practices' variables with respect to CFP.

Analysis of individual green practices' effects on CFP reveals that the elasticity of Tobin's q to PPI is the highest, followed by the elasticities of Tobin's q to GSCMI and to GPI. 10\% increase in PPI in the previous year leads to around $0.5 \%$ increase in the current Tobin's q (model 1), while 10\% increases in GSCMI and in GPI increase the current Tobin's q only by $0.3 \%$ and $0.2 \%$ (models 3 and 5), accordingly. A similar picture emerges in model 9 when all green practices are included in the model simultaneously. The elasticities of ROE to green practices' variables are slightly higher, but the similar pattern is observed again (PP practices lead to the highest change in ROE, and GPD practices to the lowest change, while GSCM practices are located in the middle).

In brief, the major drivers of CFP at the firm level are internal green practices (PP and GSCM), while external green practices (GPD) play a secondary role in determining CFP.

\subsection{Managerial implications}

The confirmation of Hypotheses 1,2 and 3 allows the authors to emphasize some important implications for managers. Given the growing attention that top managers worldwide pay to the adoption and execution of corporate environmental strategies, it is important that they understand the key green practices affecting their CFP. PP, GSCM and GPD practices cover different organizational aspects of 'being green', but all of them bring economic benefits for a company: PP can help to reduce costs and risks, GSCM can help to develop unique environmental competences and environmental collaborations across the value chain, while GPD practices can improve corporate reputation and help to obtain higher market share. A company may achieve multiple objectives through combination of several different green practices simultaneously leading to sustainable value for all stakeholders involved.

Regarding EMS, it might be the case that ISO standards help to develop unique organizational capabilities that were not captured by the measures adopted in this study. However, before allocating massive amounts of capital for implementation of ISO standards, it is important to understand the heterogeneity of the expected outcomes and that these outcomes are highly influenced by the level of internalization of their requirements in daily practices. It could be useful to reinforce the role of ISO 14001 standard in order to increase the reliability of this instrument by removing existing doubts on its efficacy and reducing the possibility to adopt it in a symbolic behavior (Testa et al., 2015a). The new version of ISO 14001 seems to have taken the right direction but more attention shall be devoted to the implementation phase.

The secondary role of GPD compared to internal practices highlights that further actions should be carried out in order to strengthen the ability of a company to communicate environmental performance of its products. Even if consumers are increasing their attitudes towards green products as well as their willingness to pay for them (Lanzini et al., 2016), independent schemes which guarantee the truthfulness of the information concerning the environmental footprint of a product are necessary (Testa et al., 2015b).

\section{Sensitivity analysis}

To ensure robustness of the main findings reported in the previous section, a blast of robustness tests using alternative economic estimators have been conducted (Table 7).

Primarily, the explanatory model is estimated using the robust regression estimator (models 1-2), which conducts an initial screening based on Cook's distance $>1$ to eliminate influential outliers and after it conducts Huber iterations followed by biweight iterations as described by Li (1985) substituting the winsorization procedure adopted in the OLS regressions.

Secondly, the authors re-estimate the explanatory model using Zellner's seemingly unrelated regression (SUR) estimator (model 3) that controls for contemporaneous cross-equation error term correlation (Baltagi, 2008). In this context, equation (2) is used to examine the effects of corporate green practices on CFP:

$\left(Q_{i t} R O E_{i t}\right)=\beta_{0}+\beta\left(B_{i t-1}\right)+y\left(X_{i t-1}^{q} X_{i t-1}^{r o e}\right)+\left(\varepsilon_{i t} u_{i t}\right)$

where $Q_{i t}$ and $R O E_{i t}$ are proxies of Tobin's $Q$ and ROE, accordingly;

Table 6

Elasticities of the green practices' variables.

\begin{tabular}{|c|c|c|c|c|c|c|c|c|c|c|}
\hline \multirow{2}{*}{$\begin{array}{l}\text { Dependent } \\
\text { variable }\end{array}$} & Q & ROE & Q & ROE & Q & ROE & Q & ROE & $\mathrm{Q}$ & ROE \\
\hline & Model (1) & Model (2) & Model (3) & Model (4) & Model (5) & Model (6) & Model (7) & Model (8) & Model (9) & Model (10) \\
\hline PPI & $\begin{array}{l}0.052^{* * * *} \\
(13.48)\end{array}$ & $\begin{array}{l}0.088^{* * * *} \\
(8.17)\end{array}$ & & & & & & & $\begin{array}{l}0.043^{* * * *} \\
(9.19)\end{array}$ & $\begin{array}{l}0.070^{* * *} \\
(5.36)\end{array}$ \\
\hline GSCMI & & & $\begin{array}{l}0.033^{* * *} \\
(12.53)\end{array}$ & $\begin{array}{l}0.049 * * * \\
(6.69)\end{array}$ & & & & & $\begin{array}{l}0.024^{* * *} \\
(7.71)\end{array}$ & $\begin{array}{l}0.024^{* *} \\
(2.88)\end{array}$ \\
\hline GPI & & & & & $\begin{array}{l}0.023^{* * *} \\
(8.58)\end{array}$ & $\begin{array}{l}0.039^{* * * *} \\
(5.33)\end{array}$ & & & $\begin{array}{l}0.010^{* * * *} \\
(3.56)\end{array}$ & $\begin{array}{l}0.016^{*} \\
(2.04)\end{array}$ \\
\hline ISO & & & & & & & $\begin{array}{l}-0.015^{* * *} \\
(-4.40)\end{array}$ & $\begin{array}{l}0.014 \\
(1.46)\end{array}$ & $\begin{array}{l}-0.037^{* * *} \\
(-10.23)\end{array}$ & $\begin{array}{l}-0.019 \dagger \\
(-1.95)\end{array}$ \\
\hline Control variables & Yes & Yes & Yes & Yes & Yes & Yes & Yes & Yes & Yes & Yes \\
\hline Time dummies & Yes & Yes & Yes & Yes & Yes & Yes & Yes & Yes & Yes & Yes \\
\hline $\begin{array}{l}\text { Country } \\
\text { dummies }\end{array}$ & Yes & Yes & Yes & Yes & Yes & Yes & Yes & Yes & Yes & Yes \\
\hline $\begin{array}{l}\text { Industry } \\
\text { dummies }\end{array}$ & Yes & Yes & Yes & Yes & Yes & Yes & Yes & Yes & Yes & Yes \\
\hline
\end{tabular}

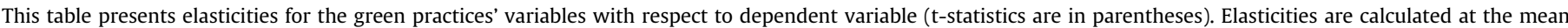

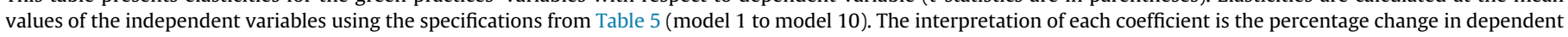

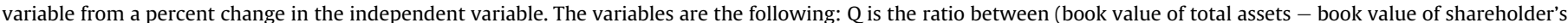

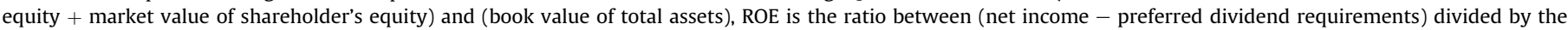

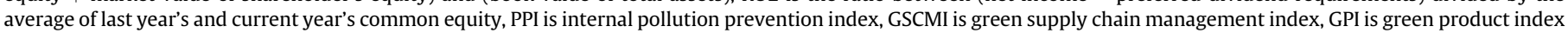

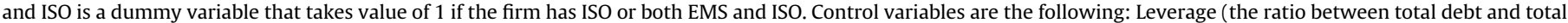

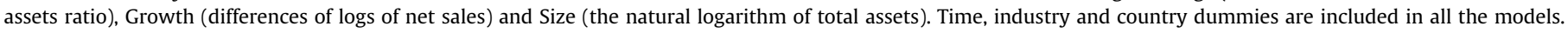
$\dagger \mathrm{p}<, 10 ;{ }^{*} \mathrm{p}<, 05 ;{ }^{* *} \mathrm{p}<, 01 ;{ }^{* * *} \mathrm{p}<, 001$. 
Table 7

Robustness check: Alternative estimation techniques.

\begin{tabular}{|c|c|c|c|c|c|c|}
\hline \multirow{3}{*}{$\begin{array}{l}\text { Method } \\
\text { Dependent } \\
\text { variable }\end{array}$} & \multicolumn{2}{|c|}{ Robust regressions } & \multicolumn{2}{|c|}{ Zellner's SUR regressions } & \multicolumn{2}{|c|}{ 2SLS regressions } \\
\hline & \multirow{2}{*}{$\frac{\mathrm{Q}}{\operatorname{Model}(1)}$} & \multirow{2}{*}{$\frac{\text { ROE }}{\text { Model (2) }}$} & Q & ROE & \multirow{2}{*}{$\frac{\mathrm{Q}}{\text { Model (4) }}$} & \multirow{2}{*}{$\frac{\mathrm{ROE}}{\text { Model (5) }}$} \\
\hline & & & & & & \\
\hline \multirow[t]{2}{*}{ Constant } & $2.753^{* * *}$ & $0.156^{* * *}$ & $4.469^{* * *}$ & $0.161^{* * *}$ & $3.856^{* * *}$ & 0.019 \\
\hline & $(45.75)$ & $(11.43)$ & $(52.67)$ & $(9.26)$ & $(39.37)$ & $(1.03)$ \\
\hline \multirow[t]{2}{*}{ Leverage } & $-0.189^{* * *}$ & $-0.033^{* * *}$ & $-0.744^{* * *}$ & $-0.046^{* * *}$ & $-0.602^{* * *}$ & $-0.125^{* * *}$ \\
\hline & $(-8.66)$ & $(-6.41)$ & $(-23.35)$ & $(-7.06)$ & $(-15.57)$ & $(-14.68)$ \\
\hline \multirow[t]{2}{*}{ Growth } & $0.182^{* * *}$ & $0.068^{* * *}$ & $0.335^{* * *}$ & $0.064^{* * *}$ & $0.535^{* * *}$ & $0.126^{* * *}$ \\
\hline & $(12.86)$ & $(21.17)$ & $(16.82)$ & $(15.62)$ & $(18.20)$ & $(17.02)$ \\
\hline \multirow[t]{2}{*}{ Size } & $-0.091^{* * *}$ & $-0.002^{*}$ & $-0.181^{* * *}$ & $-0.003^{* * *}$ & $-0.163^{* * *}$ & $0.004^{* * *}$ \\
\hline & $(-27.83)$ & $(-2.25)$ & $(-39.13)$ & $(-3.48)$ & $(-29.10)$ & $(3.40)$ \\
\hline \multirow[t]{2}{*}{ PPI } & $0.014^{* * *}$ & $0.002^{* * *}$ & $0.026^{* * *}$ & $0.003^{* * *}$ & $0.027^{* * *}$ & $0.003^{* * *}$ \\
\hline & $(6.43)$ & $(5.15)$ & $(8.80)$ & $(5.33)$ & $(7.21)$ & (3.97) \\
\hline \multirow[t]{2}{*}{ GSCMI } & $0.022^{* * *}$ & 0.001 & $0.037^{* * *}$ & $0.003^{* *}$ & $0.037^{* * *}$ & $0.003^{*}$ \\
\hline & $(6.10)$ & $(0.80)$ & $(7.31)$ & $(2.75)$ & (6.21) & $(2.15)$ \\
\hline \multirow[t]{2}{*}{ GPI } & $0.019^{* * *}$ & $0.003^{* * * *}$ & $0.022^{* * *}$ & $0.003^{*}$ & $0.021^{* *}$ & 0.002 \\
\hline & $(4.44)$ & (3.47) & (3.55) & $(2.03)$ & $(2.83)$ & (1.03) \\
\hline \multirow[t]{2}{*}{ ISO } & $-0.024^{* *}$ & $-0.004^{*}$ & $-0.121^{* * *}$ & $-0.005^{*}$ & $-0.160^{* * *}$ & $-0.007^{*}$ \\
\hline & $(-2.84)$ & $(-2.18)$ & $(-10.08)$ & $(-1.97)$ & $(-10.37)$ & $(-2.24)$ \\
\hline$Z_{1}(91)$ & 0.000 & 0.000 & 0.000 & 0.000 & 0.000 & 0.000 \\
\hline$Z_{2}(10)$ & 0.000 & 0.000 & 0.000 & 0.000 & 0.000 & 0.000 \\
\hline $\mathrm{Z}_{3}(55)$ & 0.000 & 0.000 & 0.000 & 0.000 & 0.000 & 0.000 \\
\hline $\mathrm{Z}_{4}(19)$ & 0.000 & 0.000 & 0.000 & 0.000 & 0.000 & 0.000 \\
\hline$Z_{5}$ & & & & & 0.000 & 0.000 \\
\hline$Z_{6}$ & & & & & 0.062 & 0.748 \\
\hline $\mathrm{N}$ & 21,465 & 21,049 & 20,988 & 20,988 & 18,430 & 18,037 \\
\hline Adj. $R^{2}$ & 0.238 & 0.170 & 0.289 & 0.139 & 0.273 & 0.170 \\
\hline
\end{tabular}

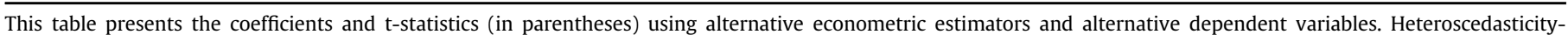

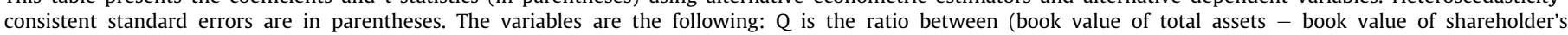

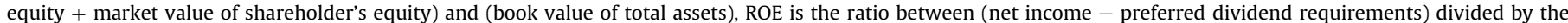

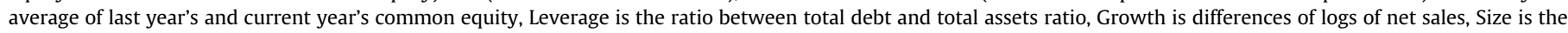

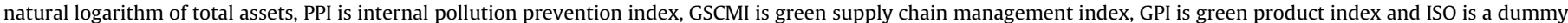

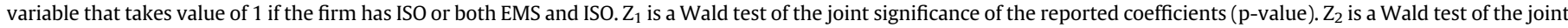

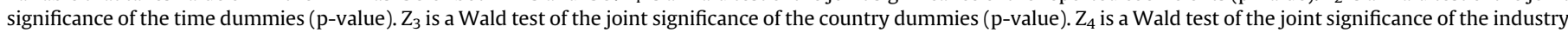
dummies (p-value). $Z_{5}$ is a Kleibergen-Paap rk LM statistic (p-value). $Z_{6}$ is Hansen's J statistic ( $p$-value). ${ }^{\dagger p}<, 10 ;{ }^{*} p<, 05 ;{ }^{* *} p<, 01 ;{ }^{* * *} p<, 001$.

$B_{i t-1}$ is a vector of green practices (PPI, GSCMI, GPI and ISO), $X^{q} i t-1$ and $X^{\text {roe }}{ }_{i t-1}$ are two vectors of control variables that are known to affect Tobin's q and ROE, including financial leverage, sales growth and firm size, time, country and industry dummies; $\varepsilon_{i t}$ and $u_{i t}$ are error terms that are correlated with each other.

Thirdly, the instrumental variable estimator (2SLS) is adopted in order to further address endogeneity problem between CFP and green practices (Rose and Stone, 2011) (models 4-5). In the first stage, green practices $\left(P P I_{i t}, G S C M I_{i t}, G P I_{i t}\right.$ and $\left.I S O_{i t}\right)$ are regressed against the internal instruments (their one- and two-year lagged values) and all other exogenous variables (Controls $s_{i t}$ ) due to the lack of good external instruments (Krafft et al., 2014). In all 2SLS regressions, instrumental variables satisfy relevancy condition (Kleibergen-Paap rk LM statistic is statistically significant at $1 \%$ level), implying that instrumental variables are correlated with potentially endogenous variables. In addition, testing for overidentifying restrictions using Hansen test does not produce significant results in any of the models suggesting that there is a lack of correlation between our instruments and error term, and thus, our instruments are valid. The instrumental variables adopted in our model satisfy both relevancy and validity conditions. In the second stage, estimates are obtained by regressing CFP on predicted values of green practices, computed using the parameters from the first-stage regression. Given that in the second-stage regressions the part of green practices that is endogenous to CFP is omitted, the parameters will now be consistently estimated.

The main findings seem to be robust to the adoption of alternative estimation techniques, with the exception of model 2 where the effect of GSCMI on ROE is not different from zero.

The sensitivity of results has been also controlled through the adoption of alternative proxies of CFP: the ratio between market value of shareholder's equity and book value of shareholder's equity (MKTBE) and ROA, defined as the ratio between earnings before interest, taxes, depreciation and amortization divided by total assets (Earnhart and Lizal, 2007) (Table 8).

As Table 8 shows, the positive effects of PPI, GSCMI, GPI and the negative effect of ISO on CFP are confirmed in all the models when MKTBE is used as a dependent variable. Concerning the link between ROA and green practices, similar results are also obtained for what concerns the PP, GSCM and ISO practices in all the models, while the effect of GPI is not statistically significant.

Estimation of the explanatory model using a natural logarithm of Tobin's q, as in Barontini and Caprio (2006), does not alter our main findings. In short, the adoption of alternative variable definitions largely confirm the empirical evidence presented in the previous section.

The sensitivity check shows that the results obtained using alternative economic estimators and alternative variable definitions confirm most of the findings of OLS regressions, with the exception of the presence of the positive link between GPD practices and ROA. The authors believe that the present analysis allows them to estimate consistently causal effects of green practices on CFP.

\section{Conclusions}

The present study clearly reveals that green practices are related to company's future market value, as well as future firm profitability, confirming the general theorization that CEP has a significant positive impact on CFP (Ambec and Lanoie, 2008). 
Table 8

Robustness check: Alternative variable definitions.

\begin{tabular}{|c|c|c|c|c|c|c|c|c|}
\hline \multirow{3}{*}{$\begin{array}{l}\text { Method } \\
\text { Dependent } \\
\text { variable }\end{array}$} & \multicolumn{2}{|c|}{ OLS regressions } & \multicolumn{2}{|c|}{ Robust regressions } & \multicolumn{2}{|c|}{ Zellner's SUR regressions } & \multicolumn{2}{|c|}{ 2SLS regressions } \\
\hline & \multirow{2}{*}{$\frac{\text { MKTBE }}{\text { Model (1) }}$} & \multirow{2}{*}{$\frac{\text { ROA }}{\text { Model (2) }}$} & \multirow{2}{*}{$\begin{array}{l}\text { MKTBE } \\
\text { Model (3) }\end{array}$} & \multirow{2}{*}{$\frac{\mathrm{ROA}}{\text { Model (4) }}$} & MKTBE & ROA & \multirow{2}{*}{$\begin{array}{l}\text { MKTBE } \\
\text { Model (6) }\end{array}$} & \multirow{2}{*}{$\frac{\mathrm{ROA}}{\text { Model (7) }}$} \\
\hline & & & & & \multicolumn{2}{|c|}{ Model (5) } & & \\
\hline Constant & $\begin{array}{l}6.922^{* * *} \\
(31.66)\end{array}$ & $\begin{array}{l}0.256^{* * *} \\
(24.55)\end{array}$ & $\begin{array}{l}4.199^{* * * *} \\
(29.10)\end{array}$ & $\begin{array}{l}0.297^{* * *} \\
(36.64)\end{array}$ & $\begin{array}{l}6.901^{* * *} \\
(33.44)\end{array}$ & $\begin{array}{l}0.256^{* * *} \\
(27.98)\end{array}$ & $\begin{array}{l}5.255^{* * *} \\
(24.88)\end{array}$ & $\begin{array}{l}0.196^{* * *} \\
(18.39)\end{array}$ \\
\hline Leverage & $\begin{array}{l}0.227^{*} \\
(2.46)\end{array}$ & $\begin{array}{l}-0.046^{* * *} \\
(-12.30)\end{array}$ & $\begin{array}{l}-0.031 \\
(-0.59)\end{array}$ & $\begin{array}{l}-0.048^{* * *} \\
(-16.13)\end{array}$ & $\begin{array}{l}0.244^{* *} \\
(3.25)\end{array}$ & $\begin{array}{l}-0.047^{* * *} \\
(-14.16)\end{array}$ & $\begin{array}{l}0.239 * \\
(2.40)\end{array}$ & $\begin{array}{l}-0.081^{* * *} \\
(-19.57)\end{array}$ \\
\hline Growth & $\begin{array}{l}0.629^{* * *} \\
(11.96)\end{array}$ & $\begin{array}{l}0.033^{* * *} \\
(10.38)\end{array}$ & $\begin{array}{l}0.436^{* * *} \\
(12.85)\end{array}$ & $\begin{array}{l}0.042^{* * *} \\
(21.61)\end{array}$ & $\begin{array}{l}0.623^{* * *} \\
(12.76)\end{array}$ & $\begin{array}{l}0.033^{* * *} \\
(15.23)\end{array}$ & $\begin{array}{l}1.149^{* * *} \\
(17.13)\end{array}$ & $\begin{array}{l}0.068^{* * * *} \\
(16.70)\end{array}$ \\
\hline Size & $\begin{array}{l}-0.317^{* * *} \\
(-26.48)\end{array}$ & $\begin{array}{l}-0.009^{* * *} \\
(-15.18)\end{array}$ & $\begin{array}{l}-0.152^{* * *} \\
(-19.45)\end{array}$ & $\begin{array}{l}-0.010^{* * *} \\
(-22.61)\end{array}$ & $\begin{array}{l}-0.315^{* * *} \\
(-28.12)\end{array}$ & $\begin{array}{l}-0.009^{* * *} \\
(-17.32)\end{array}$ & $\begin{array}{l}-0.255^{* * *} \\
(-19.52)\end{array}$ & $\begin{array}{l}-0.007^{* * *} \\
(-11.19)\end{array}$ \\
\hline PPI & $\begin{array}{l}0.043^{* * *} \\
(5.86)\end{array}$ & $\begin{array}{l}0.003^{* * *} \\
(9.60)\end{array}$ & $\begin{array}{l}0.024^{* * *} \\
(4.68)\end{array}$ & $\begin{array}{l}0.003^{* * *} \\
(9.47)\end{array}$ & $\begin{array}{l}0.043^{* * *} \\
(5.84)\end{array}$ & $\begin{array}{l}0.003^{* * *} \\
(9.43)\end{array}$ & $\begin{array}{l}0.036^{* * *} \\
(4.02)\end{array}$ & $\begin{array}{l}0.003^{* * *} \\
(8.51)\end{array}$ \\
\hline GSCMI & $\begin{array}{l}0.104^{* * *} \\
(8.52)\end{array}$ & $\begin{array}{l}0.002^{* * * *} \\
(3.72)\end{array}$ & $\begin{array}{l}0.046^{* * * *} \\
(5.27)\end{array}$ & $\begin{array}{l}0.002^{* * * *} \\
(4.17)\end{array}$ & $\begin{array}{l}0.104^{* * *} \\
(8.35)\end{array}$ & $\begin{array}{l}0.002^{* * * *} \\
(3.52)\end{array}$ & $\begin{array}{l}0.110^{* * *} \\
(7.42)\end{array}$ & $\begin{array}{l}0.002^{* *} \\
(3.25)\end{array}$ \\
\hline GPI & $\begin{array}{l}0.054^{* * *} \\
(3.74)\end{array}$ & $\begin{array}{l}0.000 \\
(0.23)\end{array}$ & $\begin{array}{l}0.060^{\text {**** }} \\
(5.78)\end{array}$ & $\begin{array}{l}0.000 \\
(0.73)\end{array}$ & $\begin{array}{l}0.059^{* * *} \\
(3.96)\end{array}$ & $\begin{array}{l}0.000 \\
(0.15)\end{array}$ & $\begin{array}{l}0.058^{* *} \\
(3.21)\end{array}$ & $\begin{array}{l}-0.000 \\
(-0.42)\end{array}$ \\
\hline ISO & $\begin{array}{l}-0.218^{* * *} \\
(-7.27)\end{array}$ & $\begin{array}{l}-0.004^{* *} \\
(-2.99)\end{array}$ & $\begin{array}{l}-0.082^{* * *} \\
(-4.02)\end{array}$ & $\begin{array}{l}-0.003^{*} \\
(-2.22)\end{array}$ & $\begin{array}{l}-0.215^{* * *} \\
(-7.34)\end{array}$ & $\begin{array}{l}-0.004^{* *} \\
(-3.06)\end{array}$ & $\begin{array}{l}-0.279^{* * *} \\
(-7.33)\end{array}$ & $\begin{array}{l}-0.006^{* * *} \\
(-3.48)\end{array}$ \\
\hline$Z_{1}(91)$ & 0.000 & 0.000 & 0.000 & 0.000 & 0.000 & 0.000 & 0.000 & 0.000 \\
\hline $\mathrm{Z}_{2}(10)$ & 0.000 & 0.000 & 0.000 & 0.000 & 0.000 & 0.000 & 0.000 & 0.000 \\
\hline $\mathrm{Z}_{3}(55)$ & 0.000 & 0.000 & 0.000 & 0.000 & 0.000 & 0.000 & 0.000 & 0.000 \\
\hline $\mathrm{Z}_{4}(19)$ & 0.000 & 0.000 & 0.000 & 0.000 & 0.000 & 0.000 & 0.000 & 0.000 \\
\hline $\mathrm{Z}_{5}$ & & & & & & & 0.000 & 0.000 \\
\hline$Z_{6}$ & & & & & & & 0.101 & 0.393 \\
\hline $\mathrm{N}$ & 21,481 & 21,310 & 21,481 & 21,310 & 21,261 & 21,261 & 18,430 & 18,280 \\
\hline Adj. $R^{2}$ & 0.208 & 0.140 & 0.222 & 0.181 & 0.211 & 0.145 & 0.208 & 0.177 \\
\hline
\end{tabular}

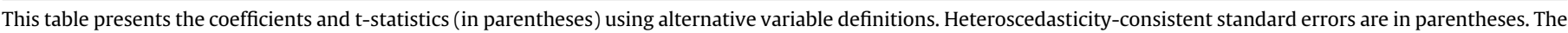

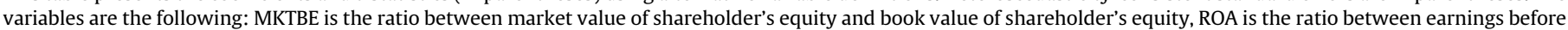

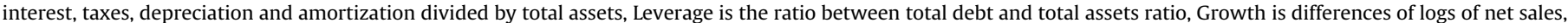

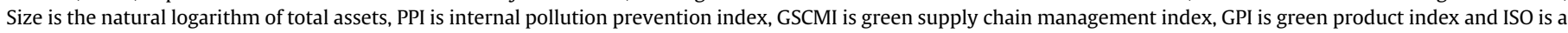

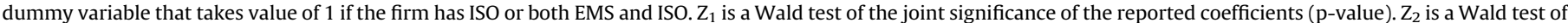

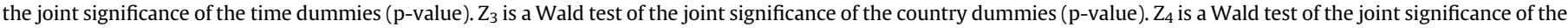
industry dummies (p-value). $Z_{5}$ is a Kleibergen-Paap rk LM statistic (p-value). $Z_{6}$ is Hansen's J statistic (p-value). †p<,10; ${ }^{*} p<, 05 ;{ }^{* *} p<, 01 ;{ }^{* * *} p<, 001$.

This paper makes significant contributions to the literature. Prior empirical studies on the green practices-CFP nexus are often based on relatively small samples, and are largely focused on a single country. Our paper expands this stream of research by using an extensive dataset covering a large sample of listed firms from 58 countries across a long time period (2002-2014). This allows us to trace the impacts of green practices on CFP in the cross-country and cross-industry setting, obtaining consistent results through different estimation techniques.

Unlike prior research that addresses the impacts of different green practices in an isolated manner (Lo et al., 2012), the present study further examines both the individual and combined effects of various green practices on both accounting- and market-based measures of CFP. This provides a new view within the environmental literature and addresses a recent research call on understanding the nexus between CFP and CEP, taking into account multidimensionality of both constructs (Endrikat et al., 2014).

Another interesting aspect of this work is the contribution to the debate in the regulatory, business, and academic communities over economic importance of corporate green practices (Testa et al., 2015a). Identifying the main green drivers of CFP, the present study provides empirical support for policy-makers, showing that environmental practices may lead to sustainable economic growth. This finding is particularly important for countries striving to green their economies through creation of sustainable value for all stakeholders involved.

The main limitations of the present study offer valuable indications for future research. Since the sample used covers only listed firms, conclusions cannot be generalized to small-andmedium enterprises (SMEs). Given that SMEs are considered the backbone of the economy (Beck et al., 2005), it can be interesting to apply the framework used in this study across SMEs.

The green practices' measures are calculated as composite indexes of various ASSET4 KPIs, aggregating a set of dummy variables, and capture only the existence of a specific green practice, but do not capture its intensity. In this context, potential avenue for future research is to develop more sophisticated proxies of green practices in order to obtain a better understanding of the green practices-CFP nexus.

Another research strategy will be to understand the mediating factors within the green practices-CFP relationship. It might be interesting to analyze whether corporate governance as a determinant of CFP (Barontini and Caprio, 2006) can also indirectly influence firm profitability and value through its impact on firm's green practices.

\section{References}

Albino, V., Balice, A., Dangelico, R.M., 2009. Environmental strategies and green product development: an overview on sustainability-driven companies. Bus. Strateg. Environ. 18, 83-96. http://dx.doi.org/10.1002/bse.638.

Ambec, S., Lanoie, P., 2008. Does it pay to be green? A systematic overview. Acad. Manag. Perspect. 22, 45-62. http://dx.doi.org/10.5465/AMP.2008.35590353.

Baltagi, B., 2008. Econometric Analysis of Panel Data, fourth ed. John Wiley and Sons, West Sussex.

Barontini, R., Caprio, L., 2006. The effect of family control on firm value and firm performance: evidence from Continental Europe. Eur. Financ. Manag 12, 689-723. http://dx.doi.org/10.1111/j.1468-036X.2006.00273.x.

Beck, T., Demirguc-Kunt, A., Levine, R., 2005. SMEs, growth, and Poverty: crosscountry evidence. J. Econ. Growth 10, 199-229. http://dx.doi.org/10.1007/ s10887-005-3533-5.

Becker-Blease, J.R., Kaen, F.R., Etebari, A., Baumann, H., 2010. Employees, firm size and profitability in U.S. manufacturing industries. Investig. Manag. Financ. Innov. 7, 119-132.

Boiral, O., 2007. Corporate greening through ISO 14001: a rational myth? Org. Sci. 18, 127-146. http://dx.doi.org/10.1287/orsc.1060.0224. 
Bose, I., Pal, R., 2012. Do green supply chain management initiatives impact stock prices of firms? Decis. Support Syst. 52, 624-634. http://dx.doi.org/10.1016/ j.dss.2011.10.020.

Carmona-Moreno, E., Céspedes-Lorente, J., De Burgos-Jiménez, J., 2004. Environmental strategies in spanish hotels: contextual factors and performance. Serv. Ind. J. 24, 101-130. http://dx.doi.org/10.1080/0264206042000247786.

Chen, Y.S., 2008. The driver of green innovation and green image - green core competence. J. Bus. Ethics 81, 531-543. http://dx.doi.org/10.1007/s10551-0079522-1.

Cheng, B., Ioannou, I., Serafeim, G., 2014. Corporate sustainability and access to finance. Strateg. Manag. J. 35, 1-23. http://dx.doi.org/10.1002/smj.2131.

Comoglio, C., Botta, S., 2012. The use of indicators and the role of environmental management systems for environmental performances improvement: a survey on ISO 14001 certified companies in the automotive sector. J. Clean. Prod. 20, 92-102. http://dx.doi.org/10.1016/j.jclepro.2011.08.022.

Corbett, C.J., Kirsch, D.A., 2001. International diffusion of ISO 14000 certification. Prod. Oper. Manag. 10, 327-342. http://dx.doi.org/10.1111/j.19375956.2001.tb00378.x.

Daddi, T., Frey, M., De Giacomo, M.R., Testa, F., Iraldo, F., 2015. Macro-economic and development indexes and ISO14001 certificates: a cross national analysis. J. Clean. Prod. 108, 1239-1248. http://dx.doi.org/10.1016/j.jclepro.2015.06.091.

Dangelico, R.M., Pontrandolfo, P., 2015. Being "green and competitive": the impact of environmental actions and collaborations on firm performance. Bus. Strateg. Environ. 24, 413-430. http://dx.doi.org/10.1002/bse.1828.

Dangelico, R.M., Pontrandolfo, P., Pujari, D., 2013. Developing sustainable new products in the textile and upholstered furniture industries: role of external integrative capabilities. J. Prod. Innov. Manag. 30, 642-658. http://dx.doi.org/ 10.1111/jpim.12013.

Darnall, N., Ji, H., Vázquez-Brust, D.A., 2016. Third-party certification, sponsorship, and consumers' ecolabel use. J. Bus. Ethics 1-17. http://dx.doi.org/10.1007/ s10551-016-3138-2.

Delmar, F., McKelvie, A., Wennberg, K., 2013. Untangling the relationships among growth, profitability and survival in new firms. Technovation 33, 276-291. http://dx.doi.org/10.1016/j.technovation.2013.02.003.

Delmas, M., 2001. Stakeholders and competitive advantage: the case of ISO 14001. Prod. Oper. Manag. 10, 343-358. http://dx.doi.org/10.1111/j.19375956.2001.tb00379.x.

Earnhart, D., Lizal, L., 2007. Effect of pollution control on corporate financial performance in a transition economy. Eur. Environ. J. 266, 247-266. http:// dx.doi.org/10.1002/eet.

Endrikat, J., Guenther, E., Hoppe, H., 2014. Making sense of conflicting empirical findings: a meta-analytic review of the relationship between corporate environmental and financial performance. Eur. Manag. J. 32, 735-751. http:// dx.doi.org/10.1016/j.emj.2013.12.004.

Feng, T., Wang, D., 2016. The influence of environmental management systems on financial performance: a moderated-mediation analysis. J. Bus. Ethics 135, 265-278. http://dx.doi.org/10.1007/s10551-014-2486-z.

Franchetti, M., 2011. ISO 14001 and solid waste generation rates in US manufacturing organizations: an analysis of relationship. J. Clean. Prod. 19, 1104-1109. http://dx.doi.org/10.1016/j.jclepro.2011.01.004.

García-Manjón, J.V., Romero-Merino, M.E., 2012. Research, development, and firm growth. Empirical evidence from European top R\&D spending firms. Res. Policy 41, 1084-1092. http://dx.doi.org/10.1016/j.respol.2012.03.017.

Gleason, K.C., Mathur, L.K., Mathur, I., 2000. The interrelationship between culture, capital structure, and performance: evidence from European retailers. J. Bus. Res. 50, 185-191. http://dx.doi.org/10.1016/s0148-2963(99)00031-4.

Golicic, S.L., Smith, C.D., 2013. A meta-analysis of environmentally sustainable supply chain management practices and firm performance. J. Supply Chain Manag. 49, 78-95. http://dx.doi.org/10.1111/jscm.12006.

Graham, S., McAdam, R., 2016. The effects of pollution prevention on performance. Int. J. Oper. Prod. Manag. 36, 1333-1358. http://dx.doi.org/10.1108/IJOPM-052015-0289.

Gusmerotti, N.M., Testa, F., Amirante, D., Frey, M., 2012. The role of negotiating tools in the environmental policy mix instruments: determinants and effects of the Environmental Agreement. J. Clean. Prod. 35, 39-49. http://dx.doi.org/10.1016/ j.jclepro.2012.05.036.

Haden, S.S.P., Oyler, J.D., Humphreys, J.H., 2009. Historical, practical, and theoretical perspectives on green management: an exploratory analysis. Manag. Decis. 47 1041-1055. http://dx.doi.org/10.1108/00251740910978287.

Halbritter, G., Dorfleitner, G., 2015. The wages of social responsibility - where are they? A critical review of ESG investing. J. Financ. Econ. 26, 25-35. http:// dx.doi.org/10.1016/j.rfe.2015.03.004.

Handfield, R., Sroufe, R., Walton, S., 2005. Integrating environmental management and supply chain strategies. Bus. Strateg. Environ. 14, 1-19. http://dx.doi.org/ $10.1002 /$ bse. 422 .

Hart, S.L., Ahuja, G., 1996. Does it pay to be green? An empirical examination of the relationship between emission reduction and firm performance. Bus. Strateg. Environ. 5, 30-37. http://dx.doi.org/10.1080/00207239908711219.

Hart, S.L., Milstein, M.B., 2003. Creating sustainable value. Acad. Manag. Exec. 17, 56-67. http://dx.doi.org/10.5465/AME.2003.10025194.

Heras-Saizarbitoria, I., Boiral, O., 2013. ISO 9001 and ISO 14001: towards a research agenda on management system standards. Int. J. Manag. Rev. 15, 47-65. http:// dx.doi.org/10.1016/j.jclepro.2013.01.040.

Heras-Saizarbitoria, I., Molina-Azorín, J.F., Dick, G.P.M., 2011. ISO 14001 certification and financial performance: selection-effect versus treatment-effect. J. Clean.
Prod. 19, 1-12. http://dx.doi.org/10.1016/j.jclepro.2010.09.002.

Heras-Saizarbitoria, I., Dogui, K., Boiral, O., 2013. Shedding light on ISO $14001 \mathrm{cer}-$ tification audits. J. Clean. Prod. 51, 88-98. http://dx.doi.org/10.1016/ j.jclepro.2013.01.040.

Hoque, A., Clarke, A., 2013. Greening of industries in Bangladesh: pollution prevention practices. J. Clean. Prod. 51, 47-56. http://dx.doi.org/10.1016/ j.jclepro.2012.09.008.

Iraldo, F., Testa, F., Frey, M., 2009. Is an environmental management system able to influence environmental and competitive performance? The case of the ecomanagement and audit scheme (EMAS) in the European Union. J. Clean. Prod. 17, 1444-1452. http://dx.doi.org/10.1016/j.jclepro.2009.05.013.

Jabbour, C.J.C., Maria Da Silva, E., Paiva, E.L., Santos, F.C.A., 2012. Environmental management in Brazil: is it a completely competitive priority? J. Clean. Prod. 21, 11-22. http://dx.doi.org/10.1016/j.jclepro.2011.09.003.

Ketikidis, P.H., Hayes, O.P., Lazuras, L., Gunasekaran, A., Lenny Koh, S.C., 2013. Environmental practices and performance and their relationships among Kosovo construction companies: a framework for analysis in transition economies. Int. J. Serv. Oper. Manag. 14, 115-130. http://dx.doi.org/10.1504/ IJSOM.2013.050565.

King, A.A., Lenox, M.J., 2001. Does it really pay to be green? J. Ind. Ecol. 5, 105-116. http://dx.doi.org/10.1162/108819801753358526.

King, A., Lenox, M., 2002. Exploring the locus of profitable pollution reduction. Manage. Sci. 48, 289-299. http://dx.doi.org/10.1287/mnsc.48.2.289.258.

Krafft, J., Qu, Y., Quatraro, F., Ravixz, J.L., 2014. Corporate governance, value and performance of firms: new empirical results on convergence from a large international database. Ind. Corp. Chang. 23, 361-397. http://dx.doi.org/10.1093/ icc/dtt007.

Kushwaha, G.S., Sharma, N.K., 2015. Green initiatives: a step towards sustainable development and firm's performance in the automobile industry. J. Clean. Prod. 121, 116-129. http://dx.doi.org/10.1016/j.jclepro.2015.07.072.

Lanzini, P., Testa, F., Iraldo, F., 2016. Factors affecting drivers' willingness to pay for biofuels: the case of Italy. J. Clean. Prod. 112, 2684-2692. http://dx.doi.org/ 10.1016/j.jclepro.2015.10.080.

Leenders, M., Chandra, Y., 2013. Antecedents and consequences of green innovation in the wine industry: the role of channel structure. Technol. Anal. Strateg. Manag. 25, 203-218. http://dx.doi.org/10.1080/09537325.2012.759203.

Leonidou, C.N., Katsikeas, C.S., Morgan, N.A., 2013. "Greening" the marketing mix: do firms do it and does it pay off? J. Acad. Mark. Sci. 41, 151-170. http:// dx.doi.org/10.1007/s11747-012-0317-2.

Li, G., 1985. Robust regression. In: Hoaglin, D.C., Mosteller, F., Tukey, W.J. (Eds.), Exploring Data Tables, Trends, and Shapes. Wiley, New York, pp. 281-340.

Lin, R.J., Tan, K.H., Geng, Y., 2013. Market demand, green product innovation, and firm performance: evidence from Vietnam motorcycle industry. J. Clean. Prod. 40, 101-107. http://dx.doi.org/10.1016/j.jclepro.2012.01.001.

Link, S., Naveh, E., 2006. Standardization and discretion: does the environmental standard ISO 14001 lead to performance benefits? IEEE Trans. Eng. Manag. 53. 508-519. http://dx.doi.org/10.1109/TEM.2006.883704.

Lo, C.K.Y., Yeung, A.C.L., Cheng, T.C.E., 2012. The impact of environmental management systems on financial performance in fashion and textiles industries. Int. J. Prod. Econ. 135, 561-567. http://dx.doi.org/10.1016/j.ijpe.2011.05.010.

Long, J.S., Ervin, L.H., 2000. Using heteroscedasticity consistent standard errors in the linear regression model. Amer. Stat. 54, 217-224. http://dx.doi.org/10.2307/ 2685594.

Lucas, M.T., Noordewier, T.G., 2016. Environmental management practices and firm financial performance: the moderating effect of industry pollution-related factors. Int. J. Prod. Econ. 175, 24-34. http://dx.doi.org/10.1016/ j.ijpe.2016.02.003.

Newbold, J., 2006. Chile's environmental momentum: ISO 14001 and the large-scale mining industry - Case studies from the state and private sector. J. Clean. Prod. 14, 248-267. http://dx.doi.org/10.1016/j.jclepro.2004.05.010.

$\mathrm{Ng}$, A.C., Rezaee, Z., 2015. Business sustainability performance and cost of equity capital. J. Corp. Financ. 34, 128-149. http://dx.doi.org/10.1016/ j.jcorpfin.2015.08.003.

Nishitani, K., 2009. An empirical study of the initial adoption of ISO 14001 in Japanese manufacturing firms. Ecol. Econ. 68, 669-679. http://dx.doi.org/10.1016/ j.ecolecon.2008.05.023.

Nishitani, K., Kaneko, S., Fujii, H., Komatsu, S., 2011. Effects of the reduction of pollution emissions on the economic performance of firms: an empirical analysis focusing on demand and productivity. J. Clean. Prod. 19, 1956-1964. http://dx.doi.org/10.1016/j.jclepro.2011.06.021.

Nissinen, A., Grönroos, J., Heiskanen, E., Honkanen, A., Katajajuuri, J.-M., Kurppa, S. Mäkinen, T., Mäenpää, I., Seppälä, J., Timonen, P., Usva, K., Voutilainen, Y.V.P., 2007. Developing benchmarks for consumer-oriented life cycle assessmentbased environmental information on products, services and consumption patterns. J. Clean. Prod. 15, 538-549. http://dx.doi.org/10.1016/ j.jclepro.2006.05.016

Opler, T.C., Titman, S., 1995. Financial distress and corporate performance. J. Finance 49, 1015-1040. http://dx.doi.org/10.1111/j.1540-6261.1994.tb00086.x.

O'Brien, R.M., 2007. A caution regarding rules of thumb for variance inflation factors. Qual. Quant. 41, 673-690. http://dx.doi.org/10.1007/s11135-006-9018-6.

Porter, M.E., van der Linde, C., 1995. Toward a new conception of the environmentcompetitiveness relationship. J. Econ. Perspect. 9, 97-118.

Potoski, M., Prakash, A., 2005. Covenants with weak swords: ISO 14001 and facilities' environmental performance. J. Policy Anal. Manag. 24, 745-769. http:// dx.doi.org/10.1002/pam.20136. 
Pujari, D., 2006. Eco-innovation and new product development: understanding the influences on market performance. Technovation 26, 76-85. http://dx.doi.org/ 10.1016/j.technovation.2004.07.006.

Rose, R.A., Stone, S.I., 2011. Instrumental variable estimation in social work research: a technique for estimating causal effects in nonrandomized settings. J. Soc. Soc. Work Res. 2 (2), 76-88. http://dx.doi.org/10.5243/jsswr.2011.4.

Sánchez-Ballesta, J.P., García-Meca, E., 2007. A meta-analytic vision of the effect of ownership structure on firm performance. Corp. Gov. 15, 879-892. http:// dx.doi.org/10.1111/j.1467-8683.2007.00604.x.

Sarkis, J., 2003. A strategic decision framework for green supply chain management. J. Clean. Prod. 11, 397-409. http://dx.doi.org/10.1016/S0959-6526(02)00062-8.

Sarkis, J., Cordeiro, J.J., 2001. An empirical evaluation of environmental efficiencies and firm performance: pollution prevention versus end-of-pipe practice. Eur. J. Oper. Res. 135, 102-113. http://dx.doi.org/10.1016/S0377-2217(00)00306-4.

Shaukat, A., Qiu, Y., Trojanowski, G., 2015. Board attributes, corporate social responsibility strategy, and corporate environmental and social performance. J. Bus. Ethics. http://dx.doi.org/10.1007/s10551-014-2460-9.

Srivastava, S.K., 2007. Green supply-chain management: a state of-the-art literature review. Int. J. Manag. Rev. 9 (1), 53-80. http://dx.doi.org/10.1111/j.14682370.2007.00202.x.

Testa, F., Iraldo, F., 2010. Shadows and lights of GSCM (Green Supply Chain Management): determinants and effects of these practices based on a multinational study. J. Clean. Prod. 18, 953-962. http://dx.doi.org/10.1016/ j.jclepro.2010.03.005.

Testa, F., Rizzi, F., Daddi, T., Gusmerotti, N.M., Iraldo, F., Frey, M., 2014. EMAS and ISO 14001: the differences in effectively improving environmental performance. J. Clean. Prod. 68, 165-173. http://dx.doi.org/10.1016/j.jclepro.2013.12.061.
Testa, F., Boiral, O., Iraldo, F., 2015a. Internalization of environmental practices and institutional complexity: can stakeholders pressures encourage greenwashing? J. Bus. Ethics 1-21. http://dx.doi.org/10.1007/s10551-015-2960-2.

Testa, F., Iraldo, F., Vaccari, A., Ferrari, E., 2015b. Why eco-labels can be effective marketing tools: evidence from a study on Italian consumers. Bus. Strateg. Environ. 24, 252-265. http://dx.doi.org/10.1002/bse.1821.

Testa, F., Nucci, B., Tessitore, S., Iraldo, F., Daddi, T., 2016. Perceptions on LCA implementation: evidence from a survey on adopters and nonadopters in Italy. Int. J. Life Cycle Assess. 1-13. http://dx.doi.org/10.1007/s11367-016-1106-9.

Tsai, M.T., Chuang, L.M., Chao, S.T., Chang, H.P., 2012. The effects assessment of firm environmental strategy and customer environmental conscious on green product development. Environ. Monit. Assess. 184, 4435-4447. http:// dx.doi.org/10.1007/s10661-011-2275-4.

Wahba, H., 2008. Does the market value corporate environmental responsibility? An empirical examination. Corp. Soc. Responsib. Environ. Manag. 15, 89-99. http://dx.doi.org/10.1002/csr.153.

Watson, K., Klingenberg, B., Polito, T., Geurts, T.G., 2004. Impact of environmental management system implementation on financial performance: a comparison of two corporate strategies. Manag. Environ. Qual. 15, 622-628. http:// dx.doi.org/10.1108/14777830410560700.

Zhu, Q., Sarkis, J., 2004. Relationships between operational practices and performance among early adopters of green supply chain management practices in Chinese manufacturing enterprises. J. Oper. Manag. 22, 265-289. http:// dx.doi.org/10.1016/j.jom.2004.01.005.

Zhu, Q., Sarkis, J., Geng, Y., 2005. Green supply chain management in China: pressures, practices and performance. Int. J. Oper. Prod. Manag. 25, 449-468. http:// dx.doi.org/10.1108/01443570510593148. 